\title{
AN APPLICATION OF KELLER'S BRAND EQUITY MODEL IN A B2B CONTEXT
}

\author{
Kerri-Ann L. Kuhn* \\ Griffith Business School \\ Department of Marketing \\ Griffith University \\ Brisbane, QLD 4111 Australia \\ PH: +61 737353729 \\ FAX: +61 737357126 \\ K.Kuhn@Griffith.edu.au \\ *Corresponding author \\ Frank Alpert \\ Griffith Business School \\ Department of Marketing \\ Griffith University \\ Brisbane, QLD 4111 Australia \\ PH: +61 737357344 \\ FAX: +61 737357126 \\ F.Alpert@Griffith.edu.au \\ Nigel K. Ll. Pope \\ Griffith Business School \\ Department of Marketing \\ Griffith University \\ Brisbane, QLD 4111 Australia \\ PH: +61 737357111 \\ FAX: +61 737357126 \\ n.pope@griffith.edu.au
}




\title{
AN APPLICATION OF KELLER'S BRAND EQUITY MODEL IN A B2B CONTEXT
}

\begin{abstract}
Purpose: The importance of branding in industrial contexts has increased, yet a comprehensive model of business-to-business (B2B) branding does not exist, nor has there been a thorough empirical study of the applicability of a full brand equity model in a B2B context. This paper discusses the fit and limitations of Keller's Customer-Based Brand Equity (CBBE) and tests its applicability in a B2B market. The study examines where the model can aid in determining B2B brand strength, identifies dimensions relevant to industrial brands, and begins the process of developing a Keller -based B2B brand equity framework.
\end{abstract}

Methodology/Approach: The research employed semi-structured interviews to investigate brands of electronic tracking systems for waste management, with subjects being key buying centre members at the Australian local government level.

Findings: The results reveal that amongst organisational buyers there is a much greater emphasis on the selling organisation, including its corporate brand, credibility and staff, than on individual brands and their associated dimensions.

Research limitations/implications: As he study is conducted only within one industry there is a risk the results may represent industry-specific factors that are not representative of all B2B markets. Future research that validates the importance of the Keller elements in other industrial marketing contexts would be beneficial.

Practical implications: The findings have practical application and are relevant for marketing practitioners, researchers and managers as a starting point for their B2B brand equity research.

Originality/value: Detailed insights and key lessons from the field with regards to how B2B brand equity should be conceptualised and measured are offered.

Keywords: Business-to-business branding; brand equity; buyer behaviour Article type: Research paper 


\section{Introduction}

Powerful brands create meaningful images in the minds of customers (Keller, 1993), with brand image and reputation enhancing differentiation and having a positive influence on buying behaviour (Gordon et al., 1993; McEnally and de Chernatony, 1999). Branding in consumer markets can improve financial performance and long-term competitive position (Mudambi, 2002). While the power of branding is widely acknowledged in consumer markets, the nature and importance of branding in industrial markets remains underresearched.

Many business-to-business (hereafter, B2B) strategists have claimed brand-building belongs in the consumer realm. They argue that industrial products do not need branding as it is confusing and adds little value to undifferentiated products (see, for example, Collins, 1977; Lorge, 1998; Saunders and Watt, 1979). Branding and the concept of brand equity however have become increasingly important in industrial markets where it has been shown that what a brand means to a buyer can be a determining factor in deciding between industrial purchase alternatives (Aaker, 1991). It is critical for suppliers to initiate and sustain relationships due to the small number of potential customers (Ambler, 1995). To date there is no model available to assist B2B marketers in identifying and quantifying brand value. In this paper we develop and test a prominent brand equity model in a B2B context. This makes not only a theoretical contribution by advancing branding research, but addresses a managerial need for information that will assist in the assessment of industrial branding efforts.

\section{Brand Equity in Consumer and Business Markets}

A brand is a bundle of functional, economic and psychological benefits for the end user (Ambler, 1995). Every brand retains a certain amount of brand equity, defined as the assets or liabilities associated with the brand that add to, or subtract from, the value the product provided (Aaker, 1996). This is reflected in buyers' willingness to pay a premium for a favoured brand in preference to others, recommend to peers, and give consideration to other company offerings (Hutton, 1997). 
Different sources of brand equity have been proposed. Aaker (1996) for example, proposes brand awareness, associations, other proprietary assets, perceived quality and loyalty. Often though, there is no distinction made between consumer and industrial brands. The differences between consumer and business markets have been discussed elsewhere (Hutt and Speh, 1998; Kotler, 2003), and organisational buyers have been found to differ in type of purchase and decision processes (Mudambi, 2002; Thompson et al., 1997/1998; Wilson and Woodside, 2001). It would seem reasonable that what makes a brand valuable in a B2B context will differ from that in a consumer environment.

The most comprehensive brand equity model available in the literature is Keller's (1993, 2001, 2003). Keller claims the Customer-Based Brand Equity (CBBE) model can be applied in a B2B context, but detailed analysis, a full formal adaptation (such as a redesigned questionnaire), and empirical evidence are not yet available. Keller recognises likely general differences between consumer and B2B markets and addresses general issues of B2B application, but his primary focus is on consumer markets. Grace and O’Cass (2002) recognised similar limitations in relation to services. We turn now to an overview of the specific steps in the Keller model and present a discussion drawing from B2B branding research.

\section{Elements of the Keller Model}

Brand equity, as defined by Keller (1993), occurs when a brand is known and has some strong, favourable and unique associations in a consumer's memory. As presented in Figure 1, the CBBE model identifies four steps for building a strong brand. In this branding ladder each step is dependent on successfully achieving the previous - from brand identity to brand meaning, brand responses and finally brand relationships. These steps in turn consist of six brand building blocks - salience, performance, imagery, judgments, feelings and resonance. The ultimate aim is to reach the pinnacle of the CBBE pyramid - resonance - where a completely harmonious relationship exists between customers and the brand.

\section{Take in Figure 1}

Keller's argument is as follows (Keller, 2003). The first step in building a strong brand is to ensure the correct brand identity. The purpose is to create an identification of the brand with customers, and an association in their minds with a specific product class or need. To 
do this, brand salience must exist, which represents aspects of brand awareness and the range of purchase and consumption situations in which the brand comes to mind. The salience building block is therefore made up of two sub-dimensions - need satisfaction and category identification.

Business-to-business products also possess image, association and perceptions of value, but initial awareness and associations are often achieved by direct contact with company salespeople (Gordon et al., 1993). In industrial markets branding is dependent on the surrounding distribution network (Gordon et al., 1993; Rosenbroijer, 2001), making the role of distributors particularly important in building equity. Large organisations often have a buying centre consisting of a number of parties from various departments, as well as specialists and other interest groups, all of whom impact the purchase decision (Gordon et al., 1993; Morris et al., 1999). This makes the process more complex as each member will possess different needs, and will view the purchase situation, buying criteria and alternative suppliers in various ways (Ghingold and Wilson, 1998). The Keller model is focused primarily on individuals' perceptions of brands in the assessment of brand equity, but in a B2B context these other influencers can have an impact on brand equity as well.

The second step establishes brand meaning by linking tangible and intangible brand associations. Brand meaning is therefore characterised in either functional (brand performance) or abstract (image-related) associations. Functional attributes are 1) primary ingredients and supplementary features; 2) product reliability, durability and serviceability; 3) service effectiveness, efficiency and empathy; 4) style and design; and 5) price. Image associations relate to the extrinsic properties of the product: 1 ) user profiles; 2) purchase and usage situations; 3) personality and values; and 4) history, heritage and experiences (Keller 2003).

By contrast, industrial research suggests that brand value has other components including the product, distribution services, support services and the company, each possessing both tangible and intangible elements (Low and Blois, 2002; Mudambi et al., 1997). Keller’s model tends to ignore elements relating to support services (specifically the rapport between the service provider and customer) and the company (such as profitability, market share and reputation), which may have greater importance in a B2B context. Similarly, Thompson et al. (1997/1998) identify other brand attributes associated with the industrial 
purchasing process. Again, many of these are evident in Keller's brand meaning construct but attributes such as technical capability, delivery reliability and responsiveness are not included.

It appears that quality, reliability, performance and service are primary factors for building brand loyalty in the industrial context, with quality being paramount (Bendixen et al., 2004; Michell et al., 2001; Thompson et al., 1997/1998). Keller sees this in the higher order pyramid block judgments, but ignores the customer relationship with the sales team due to his concentration on consumer markets. The sales force is a major brand-building tool for B2B marketers (Lorge, 1998). A buyer's purchase choice depends not only on their assessment of the product's functional benefits, but on their evaluation of the company's sales people (Gordon et al., 1993; Michell et al., 2001). These staff are company advocates who can affect the brand meaning in various ways (Hogg et al., 1998; Kennedy, 1977; Tilley, 1999).

The Keller pyramid is also focused on the individual brand but B2B products are often marketed under the manufacturer label, or a hybrid brand, where the company's name is used with a specific product name (Gordon et al., 1993; Michell et al., 2001). This makes the company name an important decision variable. Factors relating to the company behind the brand form only a minor part of the Keller model, but they are important in a B2B context (Selnes, 1993; Thompson et al., 1997/1998). For example, Abratt (1986) found supplier reputation to be more important than price, and Shaw et al. (1989) showed that intangible attributes are often more important than product performance.

Brand response is the third step in the Keller model and represents opinions and evaluations of the brand based on a combination of associations identified in brand meaning. These judgments include quality, credibility, consideration and superiority. Brand feelings are customers' emotional responses and reactions to the brand. Keller identifies six types: warmth, fun, excitement, security, social approval and self respect (Keller, 2003).

This approach reflects a customer focus on the functional, emotional and self-expressive benefits of brands. In contrast, industrial brand management is characterised by branding at the corporate level, with greater customer emphasis on risk-reduction than on expressive benefits (Mudambi, 2002). One way of managing and decreasing risk and uncertainty for 
the organisation is to buy leading brands from reputable companies (Mitchell, 1995; Mudambi, 2002). This supports the importance of feelings and imagery in the organisational buying context, but suggests that different types of feelings and imagery to those specified by Keller, may be required in a B2B brand equity model.

Brand relationships constitute the final step in the pyramid where brand response is converted to create an intense, active loyalty relationship between customers and the brand. The pinnacle of the pyramid is resonance, which refers to the nature of the relationship between the customer and the brand. It is described as having four elements: behavioural loyalty, attitudinal attachment, sense of community and active engagement (Keller, 2001).

Customer loyalty generating factors have also been found to be important to the success of industrial brands (Michell et al., 2001). Unlike consumer markets, the gain or loss of a few customers can significantly impact an industrial manufacturer's bottom line. This makes brand loyalty particularly important as it is, in some respects, firm loyalty (Gordon et al., 1993). Changes for one individual product may affect perceptions of all products and cause a distributor to switch suppliers in all categories after a poor experience with an individual product (Gordon et al., 1993). While there is a lack of research to confirm the existence of attitudinal attachment and a sense of community in industrial markets, there is evidence of active engagement. Hutton (1997) found willingness to communicate about the brand and make brand referrals. He also found that some organisational buyers had developed such a strong relationship with the brand they were willing to extend to other products with the same brand name.

In order to assess the applicability of the Keller model in a B2B environment and identify insights and challenges of such an application, we undertook a study of the market for electronic tracking systems for waste management. Electronic tracking systems for waste management represent an interesting market for investigation of Keller's brand equity model. The marketing of high-technology products is challenging and the use of brands has been minimal until recently (Zajas and Crowley, 1995). An increasing number of these companies however are now undertaking brand building activities with the assumption they can create an asset that generates long-term profits (Aaker and Jacobson, 2001). 


\section{Electronic Tracking Systems for Waste Management}

Australia’s Environmental Protection Agency (EPA) requires local authorities to maintain records of the generation, collection, transportation and disposal of hazardous wastes in their respective shires or counties. Legislation requires an audit trail to prevent illegal dumping of trade waste. Many local government authorities had been using a docket system similar to that operated in Europe. A need was recognised by the waste industry to use environmental management technology in order to comply with reporting requirements. In response, the profile of companies with electronic means of waste tracking was raised.

Two main competitors operate in this market, offering different types of waste tracking technologies - a bar code docket system versus a system which uses Global Positioning System (GPS) satellites. The bar code system aims to streamline the billing process, track the time and place at which a transporter is discharging waste, and identify a transporter or load in the case of disruption at a treatment plant. In addition to these benefits, the GPS system can track the movements of waste while aboard transportation vehicles and record any volume and load/unload events. The industry is in the introduction stage of the product life cycle with two councils in the process of deployment of the GPS system, and half a dozen councils using the bar code system. Other local authorities are postponing their decision as to which product they will use in order to more accurately assess the two alternatives.

The current research was conducted in two stages. First, a study was performed to obtain preliminary insights from buyers regarding branding issues. The purpose was to test a pure Keller CBBE model and identify what problems would emerge in its empirical application in a B2B context. A second study was then conducted to validate the findings and address the limitations of Study 1. A larger sample was tested using a revised questionnaire that was adapted specifically for the B2B context.

\section{Study 1}

\section{Method}

Face-to-face interviews were performed with senior management from a waste tracking company to obtain information about technology, market environment, purchase processes and councils. From this a survey instrument was developed for use with a sample of 
councils. The company provided contact details and allowed the use of its brand. A sample of five Eastern Australian councils was selected for Study 1. Councils were chosen based on their stage in the purchase decision process and their perceived level of knowledge about the two main waste tracking brands (the brand using the GPS, from here on termed Brand A, and the bar code docket system, Brand B). One council was known to be using Brand A, two were known to be using Brand B, another council was close to releasing a tender for a system, and the fifth was engaged in initial discussions with the suppliers.

Respondents within five councils were Trade Waste Officers who are responsible for the pick-up and collection of trade waste in their respective shires. They often initiate and influence the purchase decision, and ultimately use the technology. Interviews were conducted by telephone, followed a semi-structured format, and lasted up to 35 minutes. The survey consisted of a series of closed and open-ended questions, addressing each aspect of Keller's Pyramid. Questions asked respondents about the two waste tracking brands and were ordered based on the sequence of four steps and six brand building blocks in the CBBE pyramid. The second part asked respondents how they felt about the questionnaire to test their view of the content and comprehensiveness of the model. The aim was to obtain direct feedback from respondents as to their opinion of the suitability of the approach, and to identify limitations inherent in the Keller structure.

\section{Findings}

Study 1 revealed the following:

1. Respondents placed a greater emphasis on the manufacturers' corporate brand names rather than the individual product brands, and demonstrated greater awareness of these, suggesting a B2B brand equity framework needs to give major attention to the corporate brand names.

2. Respondents identified primarily with company brands and spoke about their relationships with company representatives rather than product brands.

3. Brand elements such as slogans and brand names lacked relevance to respondents who explicitly stated they were more interested in the product offering. 
4. When asked about brand associations most respondents identified product performance features, which would be categorised in Keller's performance building block. Style and design which feature in the Keller model, were not mentioned.

5. When asked what factors would be important to their councils in purchasing an electronic tracking system for waste management, respondents mentioned many factors that represent sub-dimensions of Keller's performance building block. Some new factors however, not part of the Keller model, were identified. Overall, respondents were seeking a system that could be easily implemented and used, that satisfied all the various necessary applications, and that was flexible enough to be upgraded, expanded and improved over time. Evidence of proven technologies also emerged as another important B2B performance attribute.

6. All respondents seemed to know about the activities of other councils, suggesting Keller's sub-dimensions of user profiles and purchase and usage situations have relevance in an industrial marketing context.

7. Two of Keller's sub-dimensions under the imagery brand building block were not mentioned by respondents in this research. The two waste tracking brands did not possess any personality traits or values, nor did they possess any associations related to history, heritage or experiences.

8. Aspects of the Keller brand judgments building block appeared relevant in this organisational purchasing environment, however credibility emerged as an even more important element. Respondents considered Brand B a proven product and therefore its manufacturer had more credibility. The technology of Brand A was regarded as innovative and possibly superior.

9. Keller's feelings building block lacked relevance in this market, with responses suggesting the purchase process is more rational than emotive.

10. Respondents failed to demonstrate any behavioural loyalty, attitudinal attachment, sense of community, or active engagement as per Keller's brand resonance building 
11. When asked about the suitability of the Keller model approach, one respondent mentioned he was unsure whether he should have responded based on his own personal perspective or that of his council, indicating a B2B brand equity model should take into account the role of the organisation buying centre and the brand perceptions of all members.

\section{Discussion}

Study 1 revealed difficulties in applying a pure Keller model in a B2B context, and identified further elements potentially in need of inclusion. With the small sample size however, there was the risk the results were not representative, providing justification for an extened study with a larger sample to validate the findings. Study 1 also failed to capture key insights due to the structure of the questionnaire. It was designed based on the Keller model in its pure form, therefore the purpose of the survey was to assess the equity of brands of electronic tracking systems for waste management, not their manufacturers. Respondents who were unaware of the product brand names were not asked subsequent questions relating to associations, feelings and so on, even if they were aware of the manufacturer's brand.

\section{Study 2}

The purpose of Study 2 was to take the pure Keller questionnaire from Study 1, adapt it for B2B based on the feedback and results, and then test the revised survey on a larger sample.

\section{Method}

A sample of thirty Eastern Australian local authorities was selected for Study 2. Selection was based on the population of the region represented (an indicator of whether a council has a need for an electronic tracking system for waste management is the number of constituents in the district). From a sample frame of 125 councils, those with less than 10,000 people were eliminated. Of the remaining fifty, thirty were selected based on the their system knowledge. Twenty-six useable responses were obtained. 
Telephone interviews followed a semi-structured interview format and lasted between 10 and 40 minutes. Notes taken were later transcribed into word processing files and conclusions drawn. The survey instrument was similar to Study 1 in that it consisted of a series of closed and open-ended questions. The survey was again structured in two parts, with the first consisting of questions following Keller's guidelines, and the second asking respondents about the suitability of the Keller model approach. A key limitation of the first study was that by using the Keller model in its pure form, the questions were designed to assess the equity of the individual product brands. The second questionnaire therefore assessed respondents' recognition of the corporate and product brand names for both Brands A and B, with respondents then asked about associations for each individually.

Additional questions were incorporated into the questionnaire that represented key findings of Study 1. In order to understand the role of company representatives in building brand equity and the importance of the company behind the product, respondents were asked what aspects of the company and of their relationship with company representatives would be important in considering to purchase an electronic tracking system for waste management. A question was also incorporated about credibility. Two questions were introduced to determine the existence and structure of the organisation buying centre, as well as the role of respondents in this group. The full questionnaire is provided at Appendix 1. It includes detailed instructions for the interviewer. Italicised comments explain the conceptual purpose for each question, although these could be deleted for fieldwork.

\section{Findings}

\section{Brand Awareness and Brand Elements}

Brand awareness was found to be higher overall for Brand B with brand recognition much stronger than brand recall. When asked to recall brands of electronic tracking systems for waste management, $65 \%$ of respondents could not think of any, and in only two instances respondents recalled both the manufacturer and product brands together. A total of 54\% and $96 \%$ of respondents recognised the product brand and manufacturer brand respectively for Brand B. For Brand A, 27\% of respondents recognised the product brand, while $42 \%$ recognised the manufacturer's brand. Breadth of awareness was relatively low for Brand A, with $23 \%$ of respondents correctly recalling the manufacturer when asked about companies which use GPS to monitor the movements of assets. When asked with which manufacturer 
respondents associated Brand A , only $28 \%$ correctly recalled the manufacturer. When prompted, all respondents who indicated they did not know, correctly recognised Brand A's manufacturer. Awareness of the manufacturer brand names was therefore shown to be stronger than awareness of the product brands themselves.

For Brand A and its manufacturer, strong associations were evident with GPS tracking, military technology, and one of the councils currently using the system. Associations for Brand B and its manufacturer were: waste water/trade waste/bar codes/waste tracking system, compliance and making sure things are done properly, and again, names of councils using the system. Overall, the majority of respondents listed more associations when asked about the manufacturers than when asked about the individual product brands. Most of the associations provided for the manufacturers related to the systems themselves. In many instances the same associations were listed for the manufacturer and product brands. To respondents the product brand and manufacturer brand name were synonymous.

Respondents placed more emphasis on the companies behind the brands than the brands themselves. Two respondents specifically stated they did not use the product brand when referring to the systems, but rather used the company names to distinguish between products. When asked about awareness and associations for the manufacturers and the product brands, other Trade Waste Officers expressed confusion and asked if these were the same. The results highlight the importance of measuring the equity of manufacturers' brand names.

Brand B did not have a slogan, but Brand A did. Only two respondents correctly identified the brand associated with the slogan. The implication for branding appears to be that B2B buyers care little about product slogans and more about the product offering.

\section{Brand Associations}

Key criteria for assessing brand associations in Keller's model are their perceived favourability and uniqueness. Trade Waste Officers were therefore asked open-ended questions about which factors were most favourable, least favourable and most unique about Brands A and B. Responses mostly referred to features of the products, which would fall under the Keller building block performance. Respondents focused on aspects of the 
brands that would satisfy their functional needs. It should be noted that style and design, which feature in the Keller model, were again not mentioned.

Subjects were asked what factors would be important to their councils in purchasing an electronic tracking system for waste management. The most important factors were system usability and simplicity, and cost/price. Other important factors included system reliability and dependability, compatibility with existing systems, flexibility, and reporting functionality. Many of these represent sub-dimensions of Keller's performance and imagery building blocks, however some new elements emerged.

When asked what aspects of the company behind the product were important in considering the purchase of a waste tracking system, the fact that the technology/system is proven emerged as the most important factor. Around 64\% of respondents mentioned such factors as the manufacturers' proven track record, experience in the industry and involvement with other local government authorities. Respondents indicated they wanted to see the system set up in other councils and wished to speak with these councils to gauge their satisfaction. Other important factors included after sales service and support, as well as company stability. Respondents generally wanted to see some indicator of longevity and proof the supplier would be there to assist them in the future.

When asked about associations for the manufacturers and their brands, amongst the strongest associations for both Brands A and B were the names of councils using these systems. Overall, respondents demonstrated detailed knowledge of system users. This tended to favour Brand B, which is better established in the market and more extensively used.

Similarly to Study 1, it was found the two waste tracking brands do not possess any personality traits or values, nor do they possess any associations related to history, heritage or experiences.

\section{Brand Judgments}

When asked about their overall opinion of the waste tracking brands and their quality, 50\% of respondents who were eligible to answer the question stated they did not have an opinion, or that they did not know. Respondents generally wanted some form of 
demonstration or exposure to the product before forming a judgment. Other respondents stated the systems seemed good based on their investigations or initial research.

Several respondents took into consideration the experiences of other users in forming their brand judgments. Two respondents mentioned that although they had no personal involvement with the products, they presumed the quality was decent as a result of their discussions with other councils who were comfortable with the products.

It was evident that both brands were under consideration by all respondents. Both were considered personally relevant by respondents although cost was an issue. Responses indicated Brand B was perceived to be superior to Brand A. This seemed to be due to Brand B being a proven product. The technology of Brand A was again regarded as superior.

Credibility was one element identified as being of key importance, even more important than recognised by Keller. In this market, respondents identified primarily with the manufacturer and spoke about their relationships with company representatives.

\section{Brand Feelings}

The responses suggest that feelings do not play an important role in this B2B market, suggesting the purchase process is more rational than emotive.

\section{Brand Resonance}

Brand resonance was not evident. In discussing their experiences, respondents again referred to product functionality and tangible product performance as reasons for purchasing. Some respondents, who were already using a waste tracking brand, spoke about the terms of their contracts and the possibility of switching to the competitive product following the contract completion. Behavioural loyalty appeared to be a consequence of the contract period, with respondents stating after this time they would review all products to determine which would best meet their needs at the right price. Also, although the experience of other users plays a critical role during the decision making process, the respondents did not feel any type of kinship or affiliation with other users of the same brand post-purchase. 
Nor was active engagement evident. No respondents who had purchased an electronic tracking system were willing to invest time, energy, money or other resources to get to know the brands better beyond those expended during purchase and consumption (Keller, 2003: 93). Some Trade Waste Officers indicated they speak with other local government authorities about the brands they are using, but they did not actively engage in word-ofmouth communication.

The findings reveal that the application of Keller's resonance building block in this organisational context poses difficulties. The buyers generally appeared to keep an objective, detached perspective (rather than displaying enthusiasm or advocacy). This is a major difference from consumer brands.

\section{Company Representatives and Brand Equity}

The company and its representatives play a major role in building brand equity. When asked about their relationship with the brand, respondents spoke about their relationships with company salespeople, further reinforcing that in an industrial context it is buyers and sales staff that interact, not customers and brands as in the consumer environment. When asked what aspects of their relationship with the sales team and other company representatives would be important in purchasing an electronic tracking system, respondents offered a number of insights. The most important factor was the ability to contact company representatives, followed by after-sales service/support, and staff honesty. Respondents expressed their desire to have sales staff understand their individual needs and work in partnership with them to satisfy requirements

\section{The Organisation Buying Centre}


Prior research going back many years has shown the importance of the organisational buying centre (see, for example, Robinson et al., 1967; Sheth, 1973; Spekman and Stern, 1979; Webster and Wind, 1972). For almost all respondents the decision to purchase is made by a buying centre, which involves a number of parties from across the organisation. There was no uniform structure identified across the councils surveyed, however all but one respondent mentioned others would be involved in the decision in some way. In several cases external parties connected to council were also directly involved, such as ratepayers and contracted transporters. Respondents expressed concern about the impact of the technology on these users. Almost a quarter expressed concern about equipment installation on the waste trucks specifically. Cost was also an important factor and respondents spoke about who would willingly bear this. Finally, almost $100 \%$ mentioned the regulatory body and its impact on the decision making process.

\section{Discussion}

The findings of the second study support those of Study 1, and reveal a number of dimensions that should be considered when measuring the equity of B2B brands. Many of these dimensions are found in Keller's framework, however the emphasis on some of these dimensions differs. Further factors have also been identified. We present a revised model at Figure 2.

\section{Take in fig 2 about here}

Overall, assessing the brand equity of the corporate or manufacturer brand names would seem more appropriate in a B2B context than measuring the equity of the individual product brands. Second, the salience, performance, imagery and judgments building blocks are applicable in an organisational context, although differences in the sub-dimensions for these blocks have been identified. Some brand elements such as product slogans appear to lack relevance to organisational buyers, while user profiles, purchase and usage situations and credibility are even more important than suggested by Keller. Feelings did not play a role in the industrial marketing context and the pinnacle of Keller's CBBE pyramid, resonance, may need modifications to be more relevant. Company representatives play a 
role in building brand equity, thus indicating a need for this human element to be recognised in a B2B brand equity model

An issue for a single industry case study such as this is of course that of generalisability, but the findings are consistent with those of Mudambi (2002). Mudambi’s research identified three clusters of B2B customers, each of which differs in terms of the importance of branding in the purchase decision. Respondents in the current study most closely identify with her highly tangible cluster as they indicated physical product improvements were important, and that their focus was on tangible, quantifiable and objective benefits of the products and their manufacturers. The emotional and self-expressive benefits were unimportant, but respondents highlighted the need for support from well-established, reputable and flexible manufacturers. They acknowledged the importance of a high quality physical product as well as augmented services. Mudambi claims a combination of a strong company brand and an effort to differentiate individual brands is likely to be most effective with firms in this cluster, as they are less receptive to branding. This appears to be the case in the current study.

The generalisability of our findings may be stronger for industries fitting into Mudambi’s highly tangible cluster. Our questionnaire is general enough to pick up relevant associations from other Mudambi industry clusters (such as where feelings are important), and therefore could be used as a first step in considering how to measure brand equity.

\section{Limitations and Future Research}

This research begins the assessment and adaptation of a major brand equity model for the B2B context, but it is by no means the end. Although insights and challenges have been identified in applying Keller's CBBE model, there is a risk the results may represent industry-specific factors that are not representative of all B2B markets. One potential limitation of the study is that no distinction was made between the B2B and business-togovernment environments. This represents a future research opportunity (though we suspect the basic B2B brand equity framework would apply to both). Further, in choosing trade waste management for investigation, it is possible context-specific factors even within the Mudambi highly tangible cluster may have implications limited to this market. Even those aspects that were not important in the industry studied could be important in other 
industries. Further research is therefore required to validate the findings in different industrial marketing contexts.

The advantage of the current study is that it captures detailed insights and key lessons from the field with regards to how B2B brand equity should be conceptualised and measured, by investigating real brands with real potential B2B buyers. This study is both accessible and appropriate for marketing practitioners, and even makes available a tested questionnaire adapting Keller's model. Though there are unresolved issues, it is still the most developed questionnaire available in the literature, which can serve as a starting point for managers' and researchers’ B2B brand equity research. 
APPENDIX 1: Questionnaire 
Section 1: The Waste Management Industry

Q1 When you think of companies which use the Global Positioning System or GPS to monitor the movements of assets such as vehicles and equipment, what brands can you think of? (Allow the respondent to name as many as they can) (Salience-awareness-depth-recall-product category)

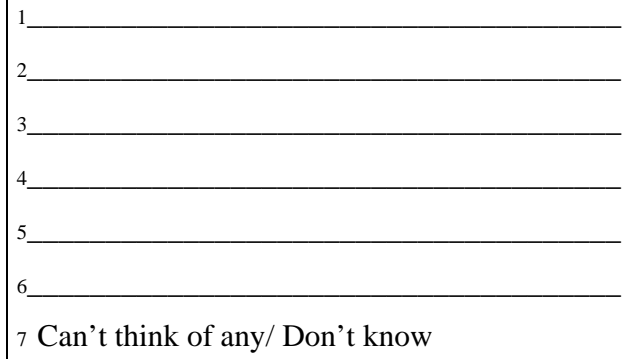

Q2 When you think of electronic tracking systems for waste management, what brands can you think of? (Allow the respondent to name as many as they can) (Salience-awareness-depth-recall-product)

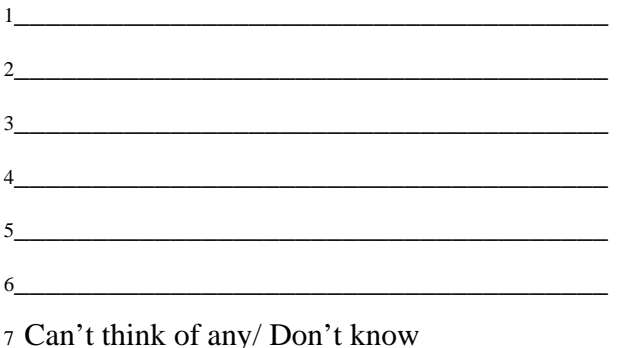

Q3 Answering yes or no, have you ever heard of these brands? (Salience-awareness-breadth-recognition)

a) Brand $\mathrm{A}$

b) Manufacturer $A$

c) Brand B

d) Manufacturer B

e) Brand C

f) Manufacturer $C$

g) Brand $\mathrm{D}$

$\begin{array}{cc}\text { Yes } & \text { No } \\ 1 \square & 2 \square \\ 1 \square & 2 \square \\ 1 \square & 2 \square \\ 1 \square & 2 \square \\ 1 \square & 2 \square \\ 1 \square & 2 \square \\ 1 \square & 2 \square\end{array}$

Q4 When I say Brand A, what are the first associations that come to your mind? Anything else?

(ASK QUESTION ONLY IF RESPONDENT ANSWERS

YES IN Q3a). (Allow the respondent to name as many as they can. Prompt for further responses)

(Salience-awareness \& usage-brand specific OR Imagerybrand meaning-brand associations)

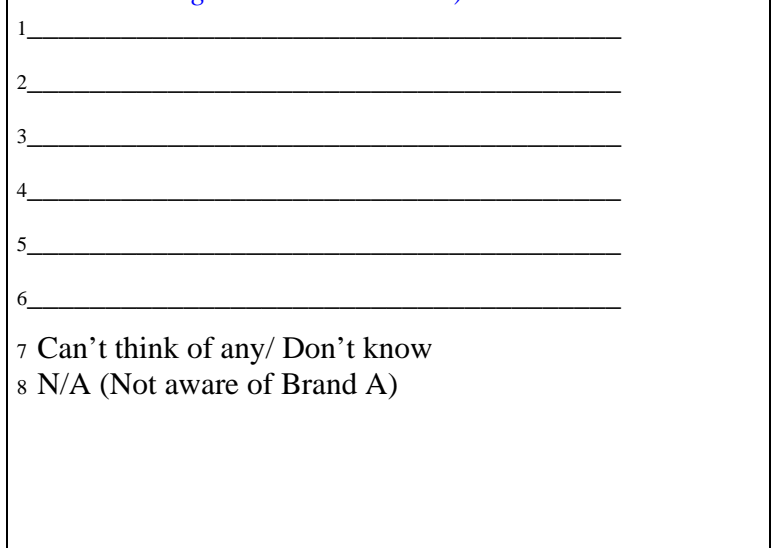

Q5 When I say Brand B, what are the first associations that come to your mind? Anything else?

(ASK QUESTION ONLY IF RESPONDENT ANSWERS YES IN Q3C)

(Allow the respondent to name as many as they can. Prompt for further responses)

(Competitor salience-awareness \& usage-brand specific OR Competitor imagery-brand meaning-brand associations)

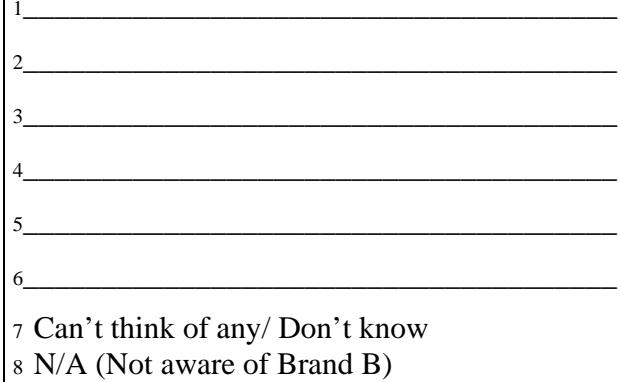

8 N/A (Not aware of Brand B)

Q6 With which company do you associate Brand A? (ASK QUESTION ONLY IF RESPONDENTANSWERS YES IN Q3a).

(Salience-awareness-depth-recall-company/brand association)

Can't think of any/ Don't know

N/A (Not aware of Brand A)

Q7 Do you associate Brand A with...?

(ASK QUESTION ONLY IF RESPONDENT ANSWERS 'DON'T KNOW' IN Q6, OTHERWISE INDICATE THEIR RESPONSE BELOW BASED ON THE PREVIOUS QUESTION)

(Salience-awareness-breadth-recognition-company/brand association)

$1 \square$ Manufacturer A

$\square$ Manufacturer E

$3 \square$ Manufacturer B

$4 \square$ A company other than those already specified

$5 \square$ N/A (Not aware of Brand A)

Q8 When I say Manufacturer A, what are the first associations that come to your mind? Anything else?

(ASK QUESTION ONLY IF RESPONDENT ANSWERS YES IN Q3b).

(Allow the respondent to name as many as they can. Prompt for further responses)

(Salience-awareness \& usage-company specific OR Imagery-brand meaning-company associations)

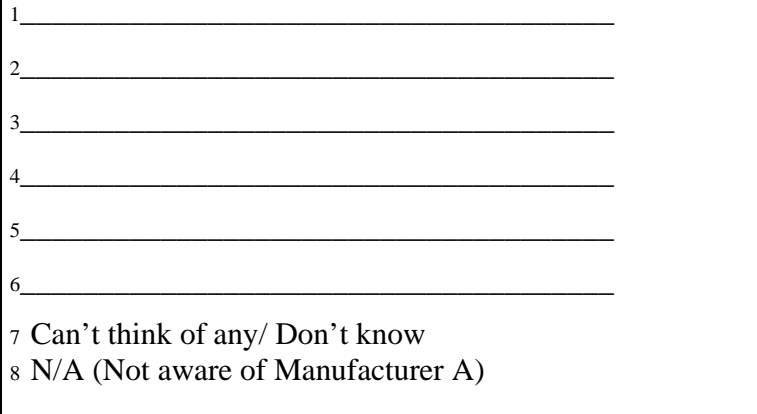


Q9 When I say Manufacturer B, what are the first associations that come to your mind? Anything else?

(ASK QUESTION ONLY IF RESPONDENT ANSWERS YES IN Q3d).

(Allow the respondent to name as many as they can. Prompt for further responses)

(Salience-awareness \& usage-company specific OR

Imagery-brand meaning-company associations)

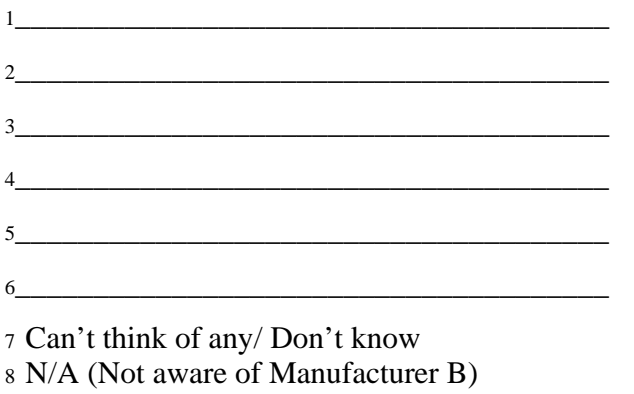

Q10 With what brand do you associate the slogan 'that which can be measured, can be improved'?

(Please tick one)

(Salience-awareness-breadth brand element)

$1 \square$ Manufacturer A

$2 \square$ Brand A

$3 \square$ A different GPS tracking brand

$4 \square$ A different company not in the satellite tracking industry

$5 \square$ I am not aware of this slogan

Q11 What does this slogan mean to you about the brand? (Please explain)

(Imagery-brand meaning- associations)

Q12 Has the council you work for purchased some type of waste management technology to monitor the collection, movement and disposal of waste?

(Salience-usage/Resonance-loyalty)

$1 \square$ Yes (Please go to question 13 \& 14)

$2 \square$ No

$3 \square$ Don’t know

Q13 From which company? (Please specify) (Salience-usage/Resonance- loyalty)

$1+2 \square$ N/A

Q14 Can you please tell me a little about your council's experience in purchasing this system.

(Please explain)

(Salience-usage/Resonance-attachment, loyalty)

$2 \square$ N/A

(IF THE RESPONDENT IS NOT AWARE OF MANUFACTURER A's BRAND A AND

MANUFACTURER B's BRAND B i.e answered 'No' to question 3a and 3d GO TO Q26)

(IF THE RESPONDENT IS AWARE OF BRAND A OR BRAND B GO TO SECTION 2 Q15)
Section 2: Electronic Tracking Systems

Q15 What is most favourable about the Manufacturer A system, Brand $A$ ?

(ASK QUESTION ONLY IF RESPONDENT ANSWERS

YES TO EITHER Q3a or b). (Performance, Imagery,

Judgments, Feelings, Resonance-Strength, Favourability)

2

3

5

7 Can't think of any/ Don't know

8 N/A (Not aware of Brand A)

Q16 What is most favourable about the Manufacturer $B$ system, Brand $B$ ?

(ASK QUESTION ONLY IF RESPONDENT ANSWERS

YES TO EITHER Q3c or d). (Competitor Performance, Imagery, Judgments, Feelings, Resonance-Strength, Favourability)

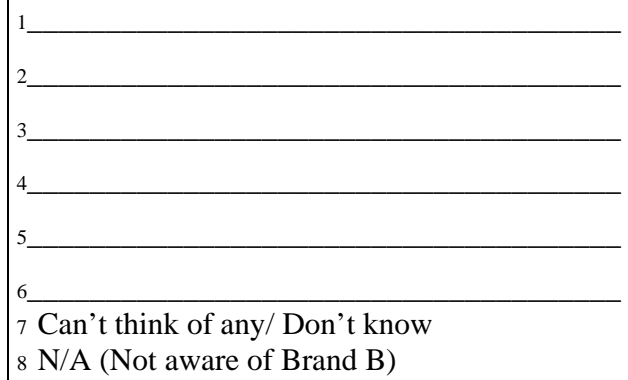

Q17 What is least favourable about Brand $A$ ? (ASK QUESTION ONLY IF RESPONDENT ANSWERS YES TO EITHER Q3a or b). (Performance, Imagery, Judgments, Feelings, Resonance-Strength Unfavourability)

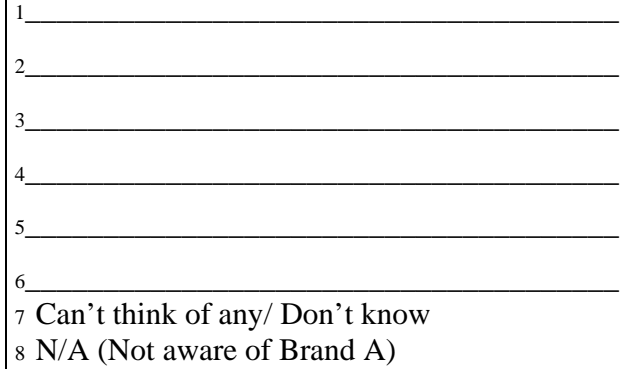

Q18 What is least favourable about Brand B? (ASK QUESTION ONLY IF RESPONDENT ANSWERS YES TO EITHER Q3c or d). (Competitor Performance, Imagery, Judgments, Feelings, Resonance-Strength, Unfavourability)

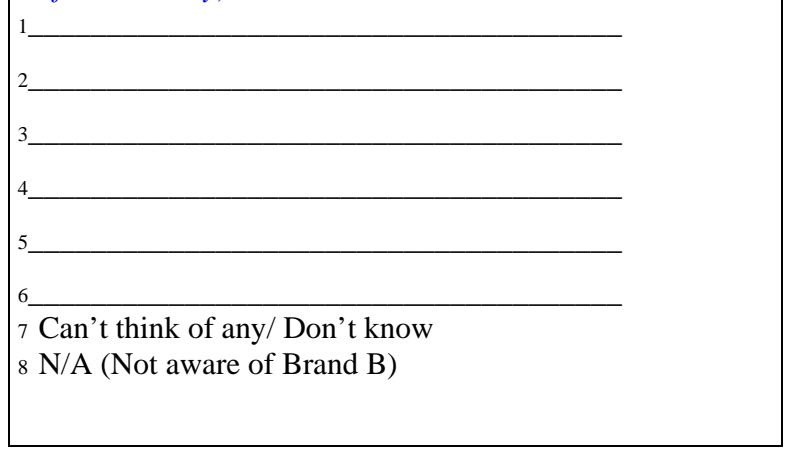


Q19 What is unique about Brand $A$ ?

(ASK QUESTION ONLY IF RESPONDENT ANSWERS

YES TO EITHER Q3a or b).

(Performance, Imagery, Judgments, Feelings, ResonanceUniqueness)

7 Can't think of any/ Don't know

8 N/A (Not aware of Brand A)

Q20 What is unique about Brand B?

(ASK QUESTION ONLY IF RESPONDENT ANSWERS

YES TO EITHER Q3c or d).

(Competitor Performance, Imagery, Judgments, Feelings,

Resonance- Uniqueness)

4

5

6

7 Can't think of any/ Don't know

8 N/A (Not aware of Brand B)

Q21 What are your feelings towards the Brand A brand? Why? (Please explain)

(ASK QUESTION ONLY IF RESPONDENT ANSWERS

YES TO Q3a). (Feelings)

Q22 How would you describe your relationship with the Brand A brand?

(ASK QUESTION ONLY IF RESPONDENT ANSWERS

YES TO Q3a).

(Resonance-attitudinal attachment)

Q23 What is your overall judgment of Manufacturer $A$ and their credibility?

(ASK QUESTION ONLY IF RESPONDENT ANSWERS

YES TO Q3b).

(Judgment-credibility)

Q24 How would you describe your relationship with Manufacturer $A$ and its representatives? (ASK QUESTION ONLY IF RESPONDENT ANSWERS YES TO Q3b).

(Resonance-community)
Q25 What is your overall opinion of the Brand A and/or Brand $B$ brands and their quality?

(Judgments-brand quality) 1

Q26 In considering to purchase an electronic tracking system for waste management, what is or what would be important to your council?

(Performance, Imagery, Judgments, Feelings, ResonanceStrength, Favourability)

3

4

6

7 Can't think of any/ Don't know

Q27 In considering to purchase an electronic tracking system for waste management, what aspects of the company behind the product would be important? Why?

(EXTRA: Company qualities eg mkt share, rep etc.)

Q28 What aspects of your relationship with the sales team and other company representatives would be important? Why?

(EXTRA: Relationship with the sales team)

Q29 In considering the purchase of an electronic tracking system for waste management, who would be involved in the decision to purchase? (EXTRA: Organisational buying centre)

Q30 Would the other participants in the decision making be aware of Brand $A$ or Brand $B$, and if not, would it be your job to educate them?

(EXTRA: Organisational buying centre)

Q31 What are other councils doing at present? Have you had any contact with them?

(EXTRA: Monitoring other users and the importance of customer referrals) 
Q32 What do you think about councils who use Brand A or other electronic tracking systems for waste management? (Ask which they are referring to) (Imagery-user profiles)

1.

Q33 How interested would you be in learning more about Brand A?

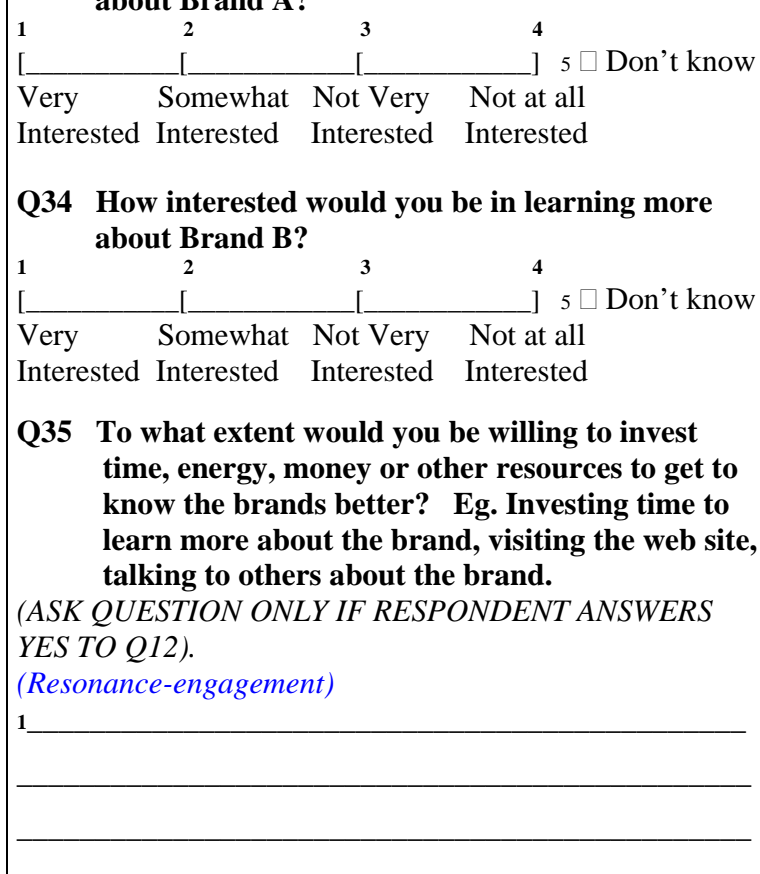

Section 3: Respondents' Views of the Survey and Applicability of the Keller Model

I would now like to ask for your help in improving this survey.

Q36 How did you find this questionnaire? Would you make any changes to this survey if you were investigating brand equity of electronic tracking systems for waste management? (Please explain)

Q37 Do you have anything that you would like to add before we conclude?

(CLOSING DIALOGUE) 'That concludes the survey. Thank you very much for your participation. If I have further questions or if I require further advice can I please contact you again in the future? ___ Thank you. I appreciate your time. (WAIT) Have a nice day. Good-bye'
(FILL IN CONTACT DETAILS IN SECTION 4 ALREADY KNOWN AFTER HANGING UP FROM RESPONDENT. COMPLETE SECTIONS 5 \& 6 AFTER HANGING UP FROM RESPONDENT.)

\section{Section 4:Contact Details}

(Complete after hanging up from respondent)

Title: Mr / Mrs / Ms / Miss

Family Name:

Given Names:

Job Title:

Organisation:

Work Phone: ( )

Section 5:Demographics

(Complete after hanging up from respondent)

Q1 Number of liquid waste generators in the council's region?

1

Q2 Number of constituents/rate payers in the council's region?

$1 \_2 \square$ Don't know

Q3 Region of council? 1

$2 \square$ Don't know

Q4 Area of council - per capita per hectare?

1

$2 \square$ Don’t know

Section 6:Additional Notes

(Complete after hanging up from respondent)

WRITE IN REACTIONS TO QUESTIONS 
FIGURE 1:

Keller’s Customer-Based Brand Equity Pyramid
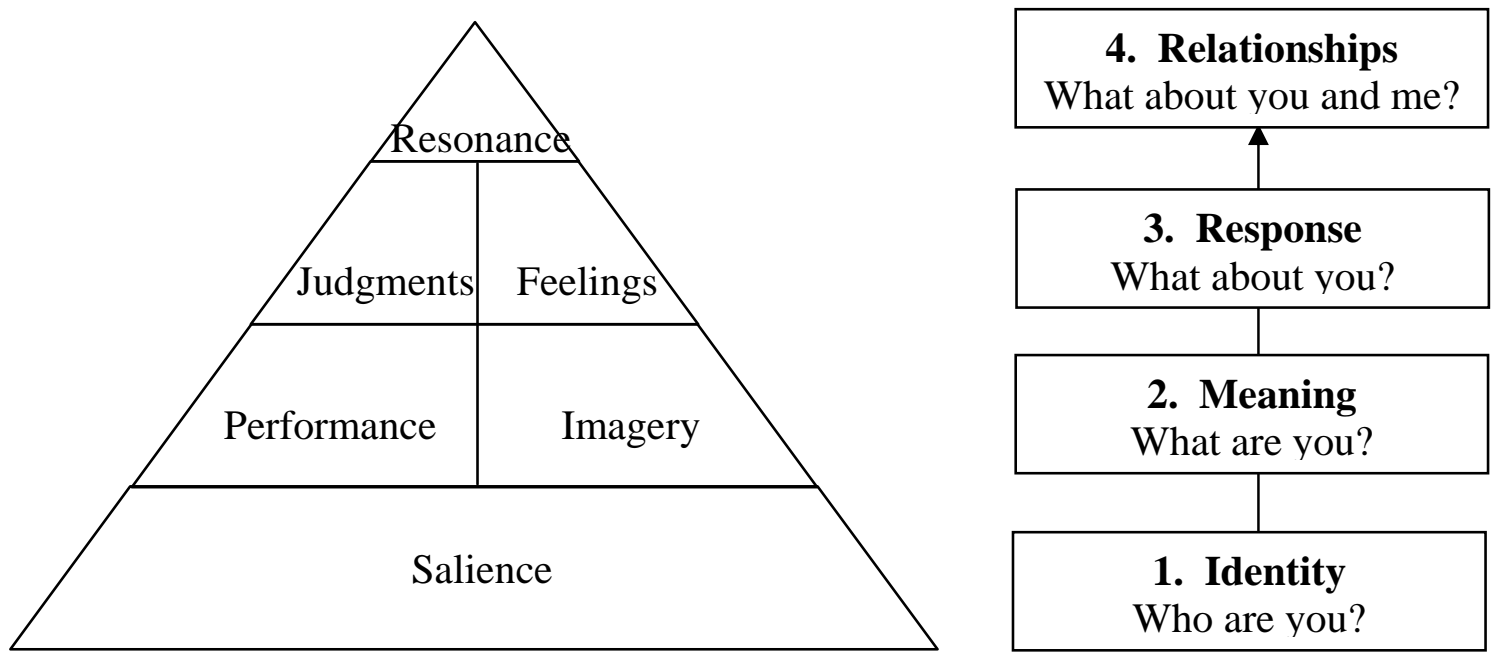

Source: Keller, 2003 
FIGURE 2:

A Revised Customer-Based Brand Equity Pyramid for B2B
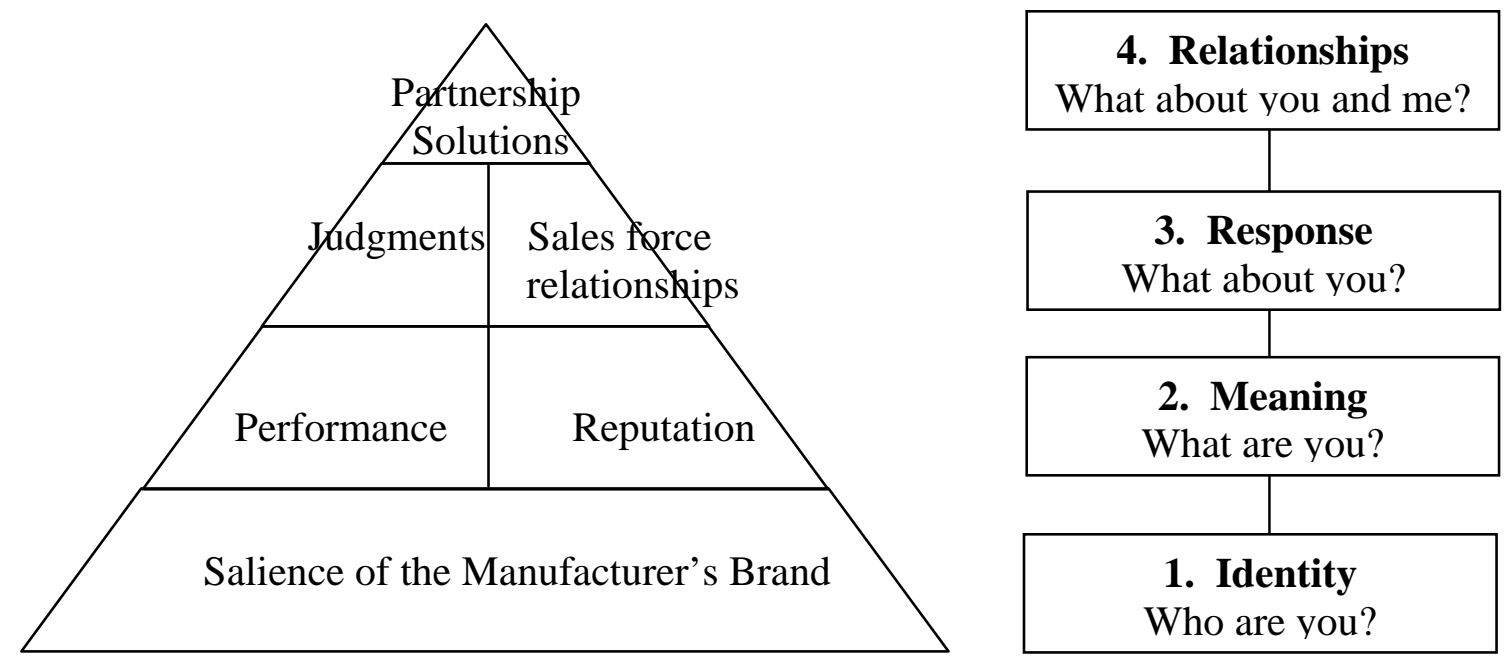

Source: Keller, 2003 and the current study 


\section{References}

Aaker, D.A. (1991), Managing Brand Equity: Capitalising on the Value of a Brand Name, Free Press, New York.

Aaker, D.A. (1996), Building Strong Brands, Free Press, New York.

Aaker, D.A. and Jacobson, R. (2001) "The value relevance of brand attitude in hightechnology markets”, Journal of Marketing Research, Vol 38 No 4, pp. 485-494.

Abratt, R. (1986) “Industrial buying in high-tech markets”, Industrial Marketing Management, Vol 15 No 4, pp. 293-298.

Abratt, R. and Mofokeng, T.N. (2001) “Development and management of corporate image in South Africa”, European Journal of Marketing, Vol 35 No 3/4, pp. 368-386.

Ambler, T. (1995) “Building brand relationships”, Financial Times Mastering Management Series, Vol Dec No 6, pp. 8-11.

Bendixen, M., Bukasa, K.A. and Abratt, R. (2004) “Brand equity in the business-tobusiness market”, Industrial Marketing Management, Vol 33 No 5, pp. 371-380.

Collins, L. (1977) “A name to conjure with - A discussion of the naming of new brands”, European Journal of Marketing, Vol 11 No 5, pp. 339-363.

Ghingold, M. and Wilson, D.T. (1998) "Buying centre research and business marketing practice: Meeting the challenge of dynamic marketing”, The Journal of Business and Industrial Marketing, Vol 13 No 2, pp. 96-108.

Gordon, G.L., Calantone, R.J. and di Benedetto, A.C. (1993) "Brand equity in the businessto-business sector: An exploratory study”, Journal of Product and Brand Management, Vol 2 No 3, pp. 4-16.

Grace, D. and O’Cass, A. (2002) “Brand associations: Looking through the eye of the beholder”, Qualitative Market Research, Vol 5 No 2, pp. 96-111.

Hogg, G., Carter, S. and Dunne, A. (1998) "Investing in people: Internal marketing and corporate culture”, Journal of Marketing Management, Vol 14 No 8, pp. 879-895.

Hutt, M.D. and Speh, T.W. (1998), Business Marketing Management: A Strategic View of Industrial and Organisational Markets, $6^{\text {th }}$ Ed, Dryden Press, Fort Worth. 
Hutton, J.G. (1997) “A study of brand equity in an organisational-buying context”, Journal of Product and Brand Management, Vol 6 No 6, pp. 428-439.

Keller, K.L. (1993) “Conceptualising, measuring and managing customer-based brand equity”, Journal of Marketing, Vol 57 No 1, pp. 1-22.

Keller, K.L. (2001) “Building customer-based brand equity”, Marketing Management, Vol 10 No 2, pp. 14-19.

Keller, K.L. (2003), Strategic Brand Management: Building, Measuring and Managing Brand Equity, $2^{\text {nd }}$ Ed, Prentice Hall, New Jersey.

Kennedy, S.H. (1977) “Nurturing corporate images”, European Journal of Marketing, Vol 11 No 1, pp. 120-164.

Knox, S. and Bickerton, D. (2003) “The six conventions of corporate branding”, European Journal of Marketing, Vol 37 No 7/8, pp. 998-1016.

Kotler, P. (2003), Marketing Management, $11^{\text {th }}$ Ed, Prentice Hall, New Jersey.

Lorge, S. (1998) “Better off branded”, Sales and Marketing Management, Vol 150 No 3, pp. 39-42.

Low, J. and Blois, K. (2002) “The evolution of generic brands in industrial markets: The challenges to owners of brand equity”, Industrial Marketing Management, Vol 31 No 5, pp. 385-392.

McEnally, M.R. and de Chernatony, L. (1999) “The evolving nature of branding: Consumer and managerial considerations”, Academy of Marketing Science Review, Vol 1999 No 2, p 1.

Michell, P., King, J. and Reast, J. (2001) “Brand values related to industrial products”, Industrial Marketing Management, Vol 30 No 5, pp. 415-425.

Mitchell, V.W. (1995) “Organisational risk perception and reduction: A literature review”, British Journal of Management, Vol 6 No 2, pp. 115-134.

Morris, M.H., Berthon, P. and Pitt, L.F. (1999) “Assessing the structure of industrial buying centres with multivariate tools”, Industrial Marketing Management, Vol 28 No 3, pp. 263276.

Mudambi, S. (2002) "Branding importance in business-to-business markets: Three buyer clusters”, Industrial Marketing Management, Vol 31 No 6, pp. 525-533. 
Mudambi, S., Doyle, P. and Wong, V. (1997) “An exploration of branding in industrial markets”, Industrial Marketing Management, Vol 26 No 5, pp. 433-446.

Reed, G., Story, V. and Saker, J. (2004) "Business-to-business marketing: What is important to the practitioner?”, Marketing Intelligence \& Planning, Vol 22 No 5, pp. 501510.

Robinson, P.J., Faris, C.W. and Wind, Y. (1967), Industrial Buying and Creative Marketing, Allyn and Bacon, Boston.

Rosenbroijer, C.J. (2001) “Industrial brand management: A distributor’s perspective in the UK fine-paper industry”, Journal of Product and Brand Management, Vol 10 No 1, pp. 725.

Saunders, J.A. and Watt, F.A. (1979) “Do brand names differentiate identical industrial products?”, Industrial Marketing Management, Vol 8 No 2, pp. 114-123.

Selnes, F. (1993) “An examination of the effect of product performance on brand reputation, satisfaction and loyalty”, European Journal of Marketing, Vol 27 No 9, pp. 1935.

Shaw, J., Giglierano, J. and Kallis, J. (1989) "Marketing complex technical products: The importance of intangible attributes”, Industrial Marketing Management, Vol 18 No 1, pp. 45-53.

Sheth, J.N. (1973) “A model of industrial buyer behaviour”, Journal of Marketing, Vol 37 No 4, pp. 50-56.

Spekman, R.E. and Stern, L.W. (1979) "Environmental uncertainty and buying group structure: An empirical investigation”, Journal of Marketing, Vol 43 No 2, pp. 54-64. Thompson, K.E., Knox, S.D. and Mitchell, H.G. (1997/1998) "Business to business brand attributes in a changing purchasing environment”, Irish Marketing Review, Vol 10 No 2, pp. 25-32.

Tilley, C. (1999) “Built-in branding: How to engineer a leadership brand”, Journal of Marketing Management, Vol 15, pp. 181-191.

Webster, F.E. and Wind, Y. (1972) “A general model for understanding organisational buying behaviour”, Journal of Marketing, Vol 36 No 2, pp. 12-19. 
Wilson, E.J. and Woodside, A.G. (2001) "Executive and consumer decision processes: Increasing useful sensemaking by identifying similarities and departures”, Journal of Business and Industrial Marketing, Vol 16 No 5, pp. 401-414.

Zajas, J. and Crowley, E. (1995) “Commentary: Brand emergence in the marketing of computers and high technology products”, Journal of Product and Brand Management, Vol 4 No 1, pp. 56-63. 